\title{
How is the anchialine fauna distributed within a cave? A study of the Ox Bel Ha System, Yucatan Peninsula, Mexico
}

\author{
Sergio Benítez', Thomas M. Iliffe², Benjamín Quiroz-Martínez³, Fernando Alvarez ${ }^{3}$ \\ I Posgrado en Ciencias del Mar y Limnología, Universidad Nacional Autónoma de México, 04510 Ciudad de \\ México, México 2 Texas A\& M University at Galveston, Department of Marine Biology, 200 Seawolf Parkway, \\ OCSB \#251, Galveston, Texas 77553, USA 3 Colección Nacional de Crustáceos, Instituto de Biología, Uni- \\ versidad Nacional Autónoma de México, 04510 Ciudad de México, México
}

Corresponding author: Sergio Benitez (sergioska99@hotmail.com)

Academic editor: Oana Moldovan | Received 6 March 2019 | Accepted 4 July 2019 | Published 11 July 2019

http://zoobank.org/BEDD0020-0DA3-4C05-B43D-D22CEA27A21B

Citation: Benítez S, Iliffe TM, Quiroz-Martínez B, Alvarez F (2019) How is the anchialine fauna distributed within a cave? A study of the Ox Bel Ha System, Yucatan Peninsula, Mexico. Subterranean Biology 31: 15-28. https://doi. org/10.3897/subtbiol.31.34347

\begin{abstract}
A study describing the diversity and distribution pattern of the stygobitic fauna in the Ox Bel Ha anchialine cave system adjacent to the Caribbean coast of the Yucatan Peninsula, Mexico is presented. A total of 15 species of crustaceans were collected in three surveys at four points situated along a $10.2 \mathrm{~km}$ transect perpendicular to the coast line. A freshwater mass dominated throughout the transect with a halocline that appeared progressively deeper, from 10 to $18 \mathrm{~m}$, with increasing distance from the coast. All the recorded species, except for one, occurred throughout the transect with no defined pattern. Abundance and species richness did not vary significantly with distance from the coast, whereas diversity $\left(\mathrm{H}^{\prime}\right)$ peaked in the second sampling site at $3.17 \mathrm{~km}$ from the coast. As expected, most of the organisms occurred only in the freshwater layer, except for the remipede Xibalbanus tulumensis (Yager, 1987) that was found always at or below the halocline, and five other species that were found above and below the halocline. In the horizontal scale, species composition and occurrence mixed without a defined pattern, both, for sampling dates and sites. The results show that the analyzed fauna is distributed throughout the $10.2 \mathrm{~km}$ transect without showing any defined horizontal zonation pointing to a high connectivity among all sections. Due to the high connectivity within the caves in the area, it is expected that significant variation in species composition and distribution will be found at a larger regional scale.
\end{abstract}

\section{Keywords}

Diversity, abundance, vertical distribution, connectivity

Copyright Sergio Benitez et al. This is an open access article distributed under the terms of the Creative Commons Attribution License (CC BY 4.0), which permits unrestricted use, distribution, and reproduction in any medium, provided the original author and source are credited. 


\section{Introduction}

The anchialine cave systems of the world have been intensely studied during the last three decades since their discovery and the improvement of diving techniques to explore them (Iliffe 2018, Iliffe and Alvarez 2018). The vast majority of studies so far conducted with anchialine fauna are of a taxonomic nature, often with descriptions of new species, or presenting new distributional records (Alvarez and Ojeda 2018, Iliffe and Alvarez 2018, Alvarez et al. 2015, 2019). Although basic ecological questions are of great importance, few studies have been published regarding the population dynamics of key species, trophic interactions and seasonal variations in diversity and abundance in these environments (Pohlman et al. 1997, Havird et al. 2015, Brankovits et al. 2017). Two main reasons have hindered the progress of this type of studies: first, the very specialized diving techniques needed to gather samples and data from the flooded cave environments (Iliffe 2018) and second, the poor knowledge about the total diversity of these systems reflected in the constant finding of new species (e.g., Alvarez et al. 2017, Suárez-Morales et al. 2017).

The anchialine caves of the Yucatan Peninsula (YP) along the Caribbean coast of Mexico between the City of Cancun and the town of Tulum (Fig. 1) are exceptionally large, some of them exceeding $250 \mathrm{~km}$ of passageways (QRSS 2018). These caves have developed in a $10-15 \mathrm{~km}$ wide band adjacent to the coast, of Pleistocene origin, at an average depth of $15 \mathrm{~m}$ (Smart et al. 2006). The caves around the town of Tulum exhibit extensive horizontal branching, are connected to the sea by defined conduits and become deeper away from the coastline.

While several studies have explored the distribution of anchialine fauna at a regional scale (Kornicker and Iliffe 1998, Alvarez and Iliffe 2008) and others have described the bathymetric distribution of the fauna and the microbial communities (Humphreys 1999, Gonzalez et al. 2011), few studies have looked at the within cave or cave system distribution. A first example is the study by Martínez-García et al. (2009) who described the diversity and distribution of anchialine fauna in the Corona lava tube in Lanzarote, Canary Islands, recognizing three main sections with different habitats and a consequent zonation of species. A second example is the study by Calderón-Gutiérrez et al. (2018) who described how density of organisms and species richness varied in four different anchialine caves in Cozumel Island, Quintana Roo, Mexico. In the latter study, the main objective was to register the diversity of organisms found in different caves, thus the differences encountered were associated to the type of cave rather than to the variety of habitats found within each cave. Part of the explanation for the absence of this type of studies is the fragmented and isolated nature of most anchialine habitats, such as sinkholes (cenotes), blueholes and coastal caves, which are studied as independent localities.

The anchialine caves of the YP are unique in terms of their extension and in the relative ease with which they can be accessed through cenotes. Although the explorations made by divers suggest that there is a high connectivity throughout most of the caves' passageways, no studies have been conducted to describe if the anchialine fauna is distributed uniformly within large caves or if there is a zonation or differential oc- 
cupation of defined habitats or sections. In this study we analyzed the spatio-temporal variation of the anchialine fauna along a $10.2 \mathrm{~km}$ transect (distance on the surface) in the $\mathrm{Ox}$ Bel $\mathrm{Ha}(\mathrm{OBH})$ anchialine cave, one of the largest underwater caves on earth (QRSS 2018). The study was designed to determine what species were present in the cave, and to test if there is a pattern of differential use of the cave's sections or if the connectivity along the passageways would allow a uniform species distribution. The working hypothesis was that diversity and abundance of anchialine organisms would decrease with increasing distance from the coast as tidal influence would fade away and the salt water layer below the halocline would be found at increasing depths.

\section{Materials and methods}

\section{Field work}

A transect was established along the northern branch of the OBH system, south of the town of Tulum, Quintana Roo, Mexico (Fig. 1). This branch runs perpendicular to the coastline, within it the penetration of marine water creates a gradient that is detected in the increasing depth of the halocline with distance from the coastline. Four cenotes were used to access the cave: Tábano $\left(20^{\circ} 10^{\prime} 8^{\prime \prime} \mathrm{N}, 87^{\circ} 27^{\prime} 22.7^{\prime \prime} \mathrm{W}\right)$, Odyssey $\left(20^{\circ} 10^{\prime} 26^{\prime \prime} \mathrm{N}, 87^{\circ} 28^{\prime} 14.6^{\prime \prime W}\right)$, Muknal $\left(20^{\circ} 11^{\prime} 19^{\prime \prime} \mathrm{N}, 87^{\circ} 29^{\prime} 24.3^{\prime \prime W}\right)$ and Bang $\left(20^{\circ} 12^{\prime} 38^{\prime \prime} \mathrm{N}, 87^{\circ} 30^{\prime} 4.1^{\prime \prime W}\right)$; situated $0.86,3.17,6.74$ and $10.17 \mathrm{~km}$ from the coastline, respectively. Three of the four cenotes are similar in size, with exposed pools ranging from 6 to $10 \mathrm{~m}$ in diameter, surrounded by dense vegetation; cenote Odyssey develops under a semicircular crack producing a half moon shape twilight zone. In three cenotes, the twilight zone gives way through restrictions to the cave zone, whereas in cenote Bang the single pool gradually becomes the cave at around $12 \mathrm{~m}$ depth. All faunal samplings were made in the cave area in complete darkness.

Three surveys were conducted in February, August and December, 2013. A group of three divers performed several tasks in each survey. First, one diver profiled the water column for temperature, salinity, dissolved oxygen concentration, $\mathrm{pH}$ and conductivity with a Hydrolab DataSonde $5 \mathrm{X}$ probe in the area where the biological sampling was going to be conducted; a second diver obtained samples from the water column above and below the halocline with two separate plankton nets with a $500 \mu \mathrm{m}$ mesh; and the third diver captured individual organisms with glass vials recording the depth at which the sample was taken.

All samplings, in the four cenotes and adjacent cave in the three sampling dates, were conducted by three divers who performed the same tasks. The divers followed the same route inside the caves in every survey. Air supply was the same for all dives which lasted between 90 and $100 \mathrm{~min}$, so that sampling effort was as similar among surveys as possible. Although neither fish nor copepods were considered in our sampling, the endemic blind brotula, Typhliasina pearsei (Hubbs, 1938), was observed in all four cenotes. All specimens were collected under the scientific collector's license issued to FA (FAUT 0104) by the Mexican environmental authority (SEMARNAT). 


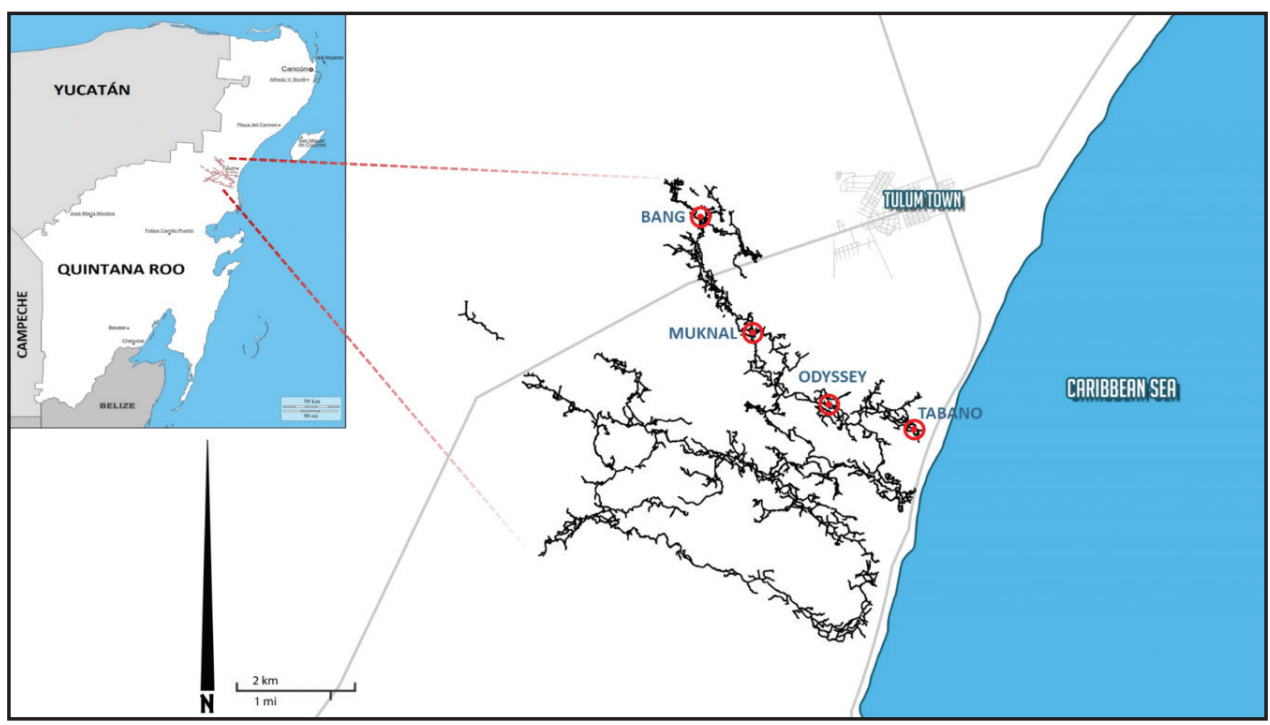

Figure I. Map of the Ox Bel Ha anchialine cave system near the town of Tulum. Quintana Roo, Mexico. The four cenotes used to access the cave were: Tábano, Odyssey, Muknal and Bang.

\section{Sample processing}

All samples were preserved in $80 \% \mathrm{EtOH}$ and all organisms identified to species. Appropriate taxonomic keys were used to identify the collected organisms: amphipods (Bowman 1977, 1987, Bowman et al. 1984, Holsinger 1990), atyid shrimps (Alvarez et al. 2005, Botello et al. 2013), hippolytid shrimps (Escobar-Briones et al. 1997), isopods (Botosaneanu and Iliffe 1997), ostracods (Kornicker and Iliffe 1998), palaemonid shrimps (Botello and Alvarez 2006, 2010), thermosbaenaceans (Bowman and Iliffe 1988), mysids (Kallmeyer and Carpenter 1996) and remipedes (Yager 1987, Olesen et al. 2017).

\section{Data analysis}

To test for differences in the distribution of organisms along the transect abundance data were tested for normality with a Kolmogorov-Smirnov test, and a Cochrane test of homocedasticity. One-way analysis of variance was used to compare abundances by site and by sampling date. In order to describe the number of species and their abundances Shannon's diversity index was obtained by site (Shannon and Weaver 1949). Hutcheson $\mathrm{t}$-tests were used to compare the diversity indices of each sampling site (Magurran 1988).

Relationships among the faunal assemblages of each cenote were examined via a similarity matrix constructed using the Jaccard's coefficient. Jaccard's similarity is, in this framework, a measure of the degree of overlap between sample points in terms of species occurrence and composition. The resulting similarity matrix was used for both cluster analysis (UPGMA) and non-metric multidimensional scaling (nMDS), as has 
been suggested by several authors (Field et al. 1982, Clarke and Warwick 2001, Legendre and Legendre 2012). To perform the above procedures we used the package "Vegan" in the statistical software R 3.1.3 (R Development Core Team 2018). To analyze the effect of environmental variables on species abundance by cenote, we run a multivariate analysis of variance ("Adonis" routine within "Vegan" package in the statistical software R 3.1.3; R Development Core Team (2018)) using distance from the coast, pH and halocline depth; we did not use salinity, dissolved oxygen concentration and temperature in this analysis because their continuous variation through the water column.

\section{Results}

\section{Water column profiles}

In cenote Tábano salinity ranged from 2 to $32 \mathrm{psu}$, with a halocline present at a depth of 11-12 m; for cenote Odyssey the values were: 0.6 to 35 psu and a halocline between 13-14 m; for cenote Muknal 0.5 to 33 psu, and a halocline between 14-15 m; and for cenote Bang 1 to $34.5 \mathrm{psu}$, and a halocline at 18-20 m depth (Fig. 3). Throughout the sampling period temperature fluctuated between 25.5 and $26.9{ }^{\circ} \mathrm{C}$ in the freshwater layer, and between 25.8 and $27.2^{\circ} \mathrm{C}$ in the saline water layer; $\mathrm{pH}$ fluctuated between 6.9 to 7.7 , and from 6.9 to 7.9 , in the freshwater and saline water layers, respectively (Table 1). The dissolved oxygen concentration (incomplete data due to equipment failure in the February sampling) showed more variation than the other parameters. In August the freshwater layer along the transect had between 0.21 and $0.78 \mathrm{mg} / \mathrm{l}$ of $\mathrm{O}_{2}$,

Table I. Water quality parameters recorded in the three samplings (February, August and December, 2013) in the four sites of the Ox Bel Ha system, Quintana Roo, Mexico: Tábano, Odyssey, Muknal, Bang. Columns correspond to: depth of the halocline in $\mathrm{m}$, salinity in psu, temperature $\left({ }^{\circ} \mathrm{C}\right), \mathrm{pH}$ and dissolved oxygen concentration in $\mathrm{mg} / \mathrm{l}\left(\left[\mathrm{O}_{2}\right]\right)$. Dashes indicate readings not taken, "NR" stands for not recorded when the halocline was deeper than the deepest surveyed area.

\begin{tabular}{|c|c|c|c|c|c|c|c|c|c|}
\hline & \multirow[b]{2}{*}{ Halocline } & \multicolumn{2}{|c|}{ Salinity } & \multicolumn{2}{|c|}{ Temperature } & \multicolumn{2}{|c|}{$\mathrm{pH}$} & \multicolumn{2}{|c|}{$\left[\mathrm{O}_{2}\right]$} \\
\hline & & $\begin{array}{c}\text { Above } \\
\text { Halocline }\end{array}$ & $\begin{array}{c}\text { Below } \\
\text { Halocline }\end{array}$ & $\begin{array}{c}\text { Above } \\
\text { Halocline }\end{array}$ & $\begin{array}{c}\text { Below } \\
\text { Halocline }\end{array}$ & $\begin{array}{c}\text { Above } \\
\text { Halocline }\end{array}$ & $\begin{array}{c}\text { Below } \\
\text { Halocline }\end{array}$ & $\begin{array}{c}\text { Above } \\
\text { Halocline }\end{array}$ & $\begin{array}{c}\text { Below } \\
\text { Halocline }\end{array}$ \\
\hline \multicolumn{10}{|l|}{ February } \\
\hline Tabano & $10-12$ & 4.34 & 30.4 & 26.9 & 27.2 & 6.9 & 7.1 & - & - \\
\hline Odyssey & $12-13$ & 4 & 32.1 & 25.7 & 26.7 & 6.8 & 7.3 & - & - \\
\hline Muknal & 13 & - & - & - & - & - & - & - & - \\
\hline Bang & $18-19$ & 2.2 & 32.7 & 25.5 & 25.8 & 6.9 & 7.4 & - & - \\
\hline \multicolumn{10}{|l|}{ August } \\
\hline Tabano & $10-11.7$ & 4.34 & 27.9 & 26.1 & 26.4 & 7.7 & 7.8 & 0.21 & 0.32 \\
\hline Odyssey & $12-12.5$ & 5.1 & 33 & 25.8 & 26.7 & 7.7 & 7.8 & 0.38 & 1.5 \\
\hline Muknal & $15-16.5$ & 2.99 & 33 & 25.6 & 26.3 & 7.6 & 7.9 & 0.78 & 1.95 \\
\hline Bang & $18-20.9$ & 2.2 & 32.8 & 25.5 & 25.8 & 7.7 & 7.8 & 0.69 & 2.1 \\
\hline \multicolumn{10}{|c|}{ December } \\
\hline Tabano & 12 & 4 & NR & 26 & NR & 6.72 & NR & 5.6 & NR \\
\hline Odyssey & $13-14$ & 4.9 & 31.9 & 25.6 & 26.4 & 6.7 & 6.9 & 0.44 & 2.42 \\
\hline Muknal & $16-18$ & 4.3 & 31.5 & 25.8 & 26.2 & 6.7 & 6.9 & 0.31 & 2.1 \\
\hline Bang & $18-20$ & 2.71 & 26.9 & 25.8 & NR & 6.5 & NR & 0.15 & NR \\
\hline
\end{tabular}


while the saline layer had 0.32 to $2.1 \mathrm{mg} / \mathrm{l}$; in December Tábano had $5.6 \mathrm{mg} / \mathrm{l}$ in the freshwater layer due to recent rains while the rest of the transect had 0.15 to $0.44 \mathrm{mg} / \mathrm{l}$ of $\mathrm{O}_{2}$. No halocline was found at the maximum depth $(12 \mathrm{~m})$ in Tábano in December due to recent rains. The general trend is one in which the halocline becomes deeper with distance from the coast, temperature and dissolved oxygen concentration are higher in the marine water mass below the halocline, and $\mathrm{pH}$ shows a small variation (Table 1).

\section{Anchialine fauna}

A total of 368 organisms were collected, 123 in cenote Tábano, 93 in Odyssey, 88 in Muknal, and 64 in Bang. Although total abundance decreases with increasing distance from the coast, mean abundance did not differ significantly along the transect (Anova, $\mathrm{F}_{[3,11]}=0.8763, \mathrm{p}=0.5039$; Fig. $\left.2 \mathrm{~A}\right)$. The total number of organisms by survey were:

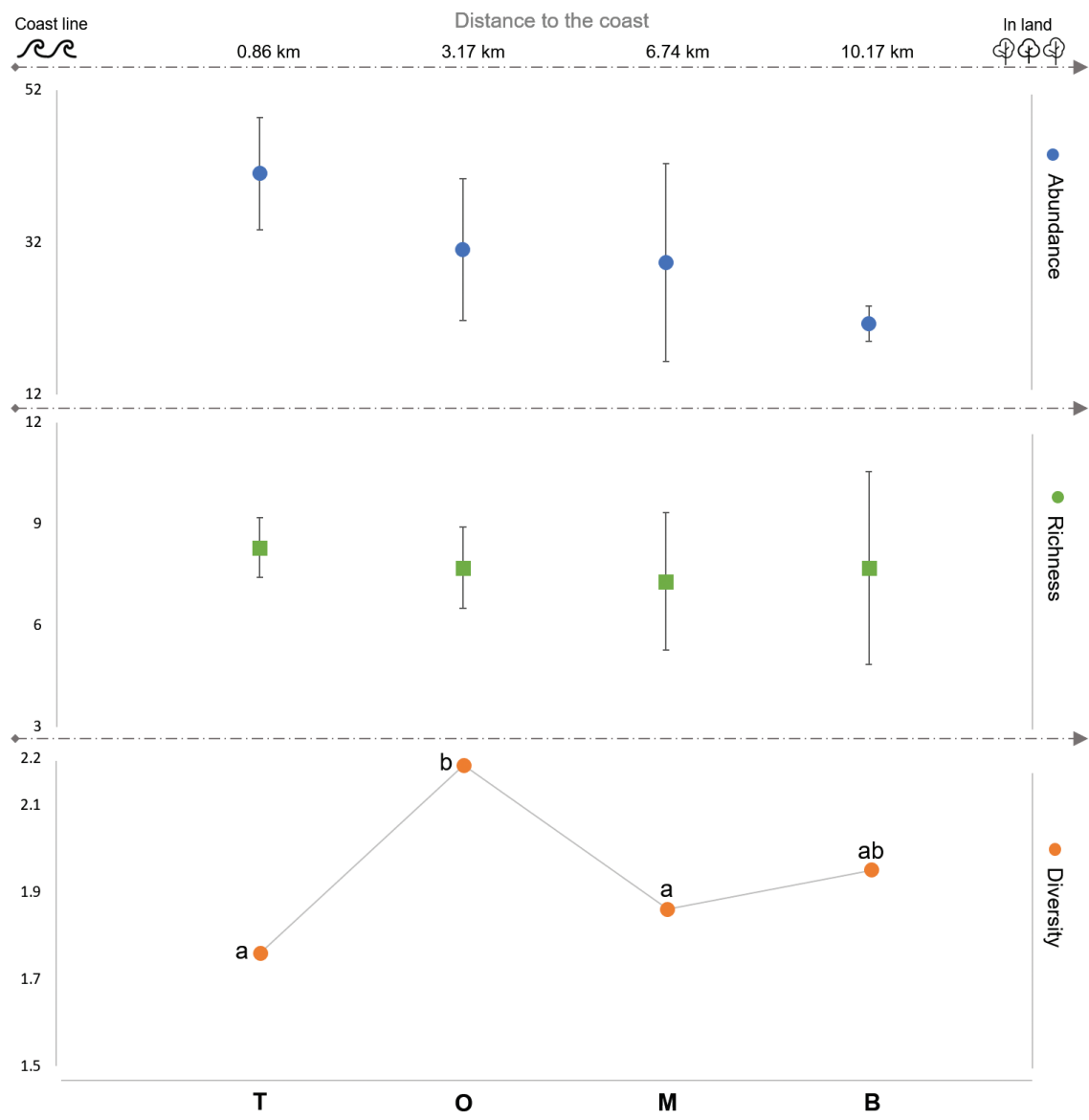

Figure 2. Ecological parameters of the anchialine fauna in the $\mathrm{Ox}$ Bel Ha anchialine cave system along a transect $\mathbf{A}$ mean \pm one standard error of the abundance $\mathbf{B}$ mean \pm one standard error of the species richness $\mathbf{C}$ Shannon's diversity index. The sites are: T, Tábano; O, Odyssey; M, Muknal; B, Bang. 
103 in February, 162 in August, and 103 in December; no significant differences were found among the mean number of organisms per survey through the year (Anova, $\left.\mathrm{F}_{[2,11]}=1.3294, \mathrm{p}=0.3438\right)$. A total of 15 species were collected, the most abundant one was the thermosbaenacean Tulumella unidens Bowman and Iliffe, 1988, with 81 organisms, followed by Typhlatya mitchelli Hobbs and Hobbs, 1976, with 79. The single rare species that was represented by one individual was the hippolytid shrimp Calliasmata nohochi Escobar-Briones, Camacho and Alcocer, 1997, found in cenote Muknal. The rest of the fauna is composed by another 12 species of crustaceans belonging to 10 different families (data available as supplementary material). The recorded diversity is about one fourth of all the anchialine fauna recorded so far from the YP (Alvarez et al. 2015, Olesen et al. 2017).

The distribution of species within the transect showed a slight variation, cenote Tábano had a total of 9 species, Odyssey 12, and Muknal and Bang 11; the mean species richness found did not differ among cenotes (Anova, $\mathrm{F}_{[3,11]}=0.25, \mathrm{p}=0.8587$; Fig. 2B); the number of species differed significantly per survey, with December having significantly less species than February and August (Anova, $F_{[2,11]}=6.4883, p$ $=0.0316)$. The only species present in all three surveys and in all four cenotes was $T$. mitchelli (Table 2). Five species (Creaseria morleyi (Creaser, 1936), Creaseriella anops (Creaser, 1936), Tulumella unidens, Tuluweckelia cernua Holsinger, 1990, Typhlatya mitchelli) occurred along the whole transect in all four cenotes. This group of species represents the most common anchialine species in the YP, occurring from the Ring of Cenotes around the City of Merida in the State of Yucatan to the Caribbean Cave Area along the coast of the State of Quintana Roo (Alvarez and Iliffe 2008). Another five species (Mayaweckelia cenoticola Holsinger, 1977, Stygiomysis holthuisi (Gordon, 1958), Typhlatya dzilamensis Alvarez, Iliffe and Villalobos, 2005, T. pearsei Creaser, 1936, Xibalbanus tulumensis) occurred in three of the four cenotes without any defined

Table 2. Occurrence of species by site (Tábano, Odyssey, Muknal, Bang) and sampling ( $\mathrm{F}=$ February, $\mathrm{A}$ = August, $\mathrm{D}=$ December) in the Ox Bel Ha system, Quintana Roo, Mexico. In blue species that occurred in the four sites, in green species that occurred in three of the four sites, in yellow species that occurred in two of the four sites and in red the single species that occurred in just one site.

\begin{tabular}{|c|c|c|c|c|c|c|c|c|c|c|c|c|}
\hline & & ba & & & dys & & & uk & & & Ban & \\
\hline & $\mathbf{F}$ & A & D & $\mathbf{F}$ & A & D & $\mathbf{F}$ & A & D & $\mathbf{F}$ & A & D \\
\hline Typhlatya mitchelli & - & - & - & - & - & - & $\bullet$ & - & $\bullet$ & - & - & - \\
\hline Tulumella unidens & - & - & - & & - & - & - & - & - & - & - & - \\
\hline Tuluweckelia cernua & - & - & & & - & - & & - & & - & - & \\
\hline Creaseriella anops & - & & & - & - & & - & - & - & - & - & \\
\hline Creaseria morleyi & & - & & - & - & & - & - & & - & & - \\
\hline Typhlatya dzilamensis & & - & - & - & - & - & - & - & & & & \\
\hline Typhlatya pearsei & - & - & - & - & & - & & & & - & & \\
\hline Stygiomysis holthuisi & - & - & & & - & & & 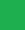 & & - & & \\
\hline Xibalbanus tulumensis & & & & & - & & & - & & & - & \\
\hline Mayaweckelia cenoticola & & - & & & & - & & & & & - & \\
\hline Antromysis cenotensis & & & & - & - & & - & - & & & & \\
\hline Humphreysella mexicana & & & & & & & - & & & & - & - \\
\hline Stygiomysis cokei & - & - & & & & & & - & & & & \\
\hline Metacirolana mayana & & & & & - & - & & & & & - & \\
\hline Calliasmata nohochi & & & & & & & & - & & & & \\
\hline
\end{tabular}




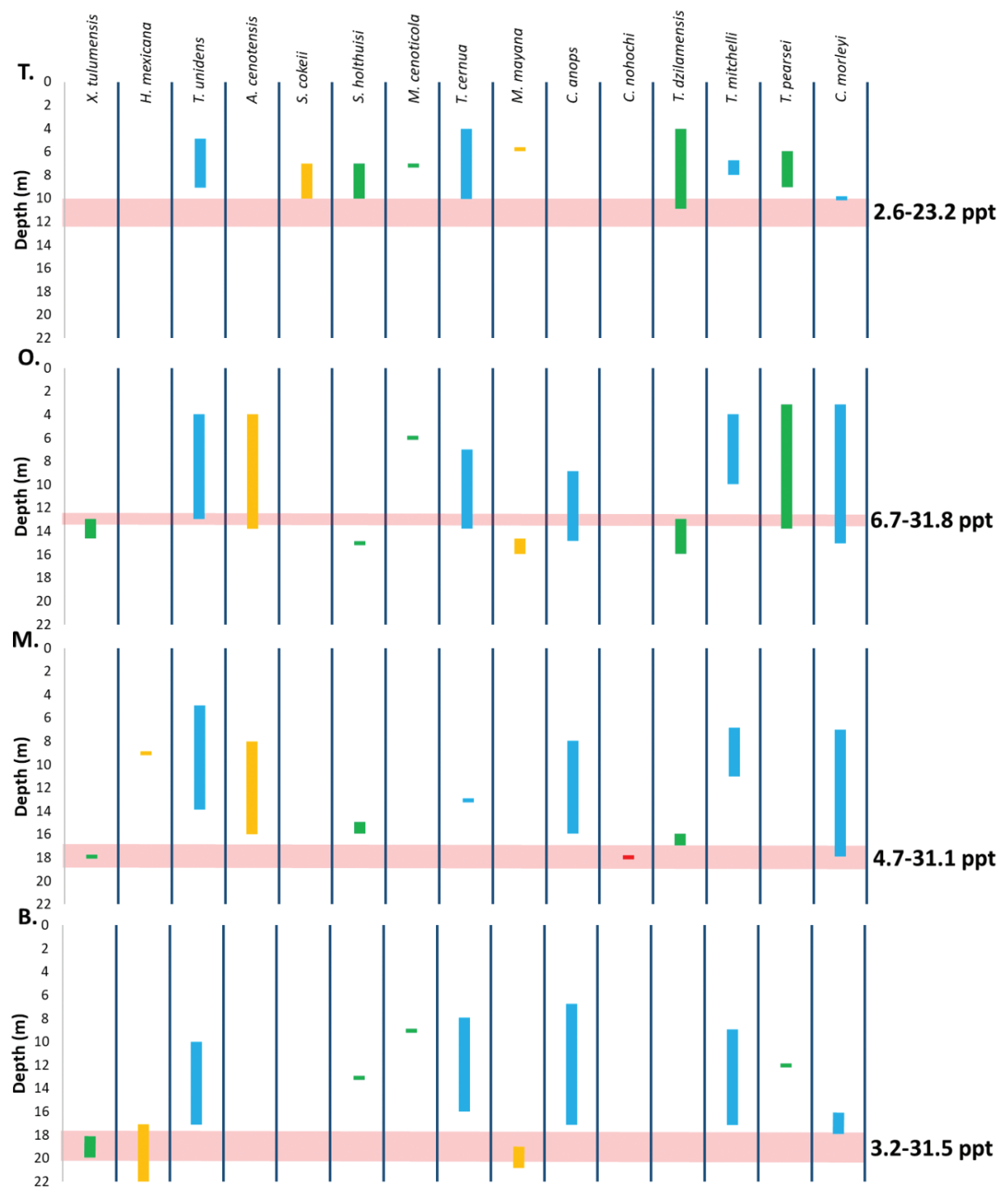

Figure 3. Distribution of organisms by species in relation to depth in the four cenotes studied in the $\mathrm{Ox}$ Bel Ha cave: A, cenote Tábano; B, cenote Odyssey; C, cenote Muknal; and D, cenote Bang. The red band depicts the halocline, its width represents the thickness of the interface.

pattern, four species (Antromysis cenotensis Creaser, 1936, Humphreysella mexicana (Kornicker \& Iliffe, 1989), Metacirolana mayana (Bowman, 1987), Stygiomysis cokei Kallmeyer \& Carpenter, 1996) were found in two cenotes and only the hippolytid shrimp Calliasmata nohochi was found in one cenote in one survey (Table 2).

Shannon's diversity index $(\mathrm{H})$ varied from 1.765 in Tabano to 2.195 in Odyssey, with Muknal and Bang having intermediate values (Fig. 2C). Odyssey diversity index 
Table 3. Results of the multivariate analysis of variance ("Adonis" routine in the statistical software package R 3.1.3; R Development Core Team (2018)) of species abundance using distance from the coast (DC), $\mathrm{pH}$ and halocline depth (Halocline).

\begin{tabular}{|c|c|c|c|c|c|c|}
\hline & Df & Sums. Of Sqs. & Mean. Sqs. & F. Model & $\mathbf{R}^{2}$ & $\operatorname{Pr}(>\mathrm{F})$ \\
\hline $\mathrm{DC}$ & 1 & 0.34744 & 0.34744 & 1.48583 & 0.13756 & 0.2079 \\
\hline $\mathrm{pH}$ & 1 & 0.37364 & 0.37364 & 1.59785 & 0.14793 & 0.1089 \\
\hline Halocline & 1 & 0.32141 & 0.32141 & 1.37451 & 0.12726 & 0.2772 \\
\hline DC: $\mathrm{pH}$ & 1 & 0.12133 & 0.12133 & 0.51888 & 0.04804 & 0.8218 \\
\hline DC: Halocline & 1 & 0.23741 & 0.23741 & 1.01526 & 0.094 & 0.4356 \\
\hline pH: Halocline & 1 & 0.11867 & 0.11867 & 0.50748 & 0.04698 & 0.8416 \\
\hline DC: pH:Halocline & 1 & 0.07044 & 0.07044 & 0.30125 & 0.02789 & 0.9604 \\
\hline Residuals & 4 & 0.93535 & 0.23384 & & 0.37033 & \\
\hline Total & 11 & 2.52568 & & & 1 & \\
\hline
\end{tabular}
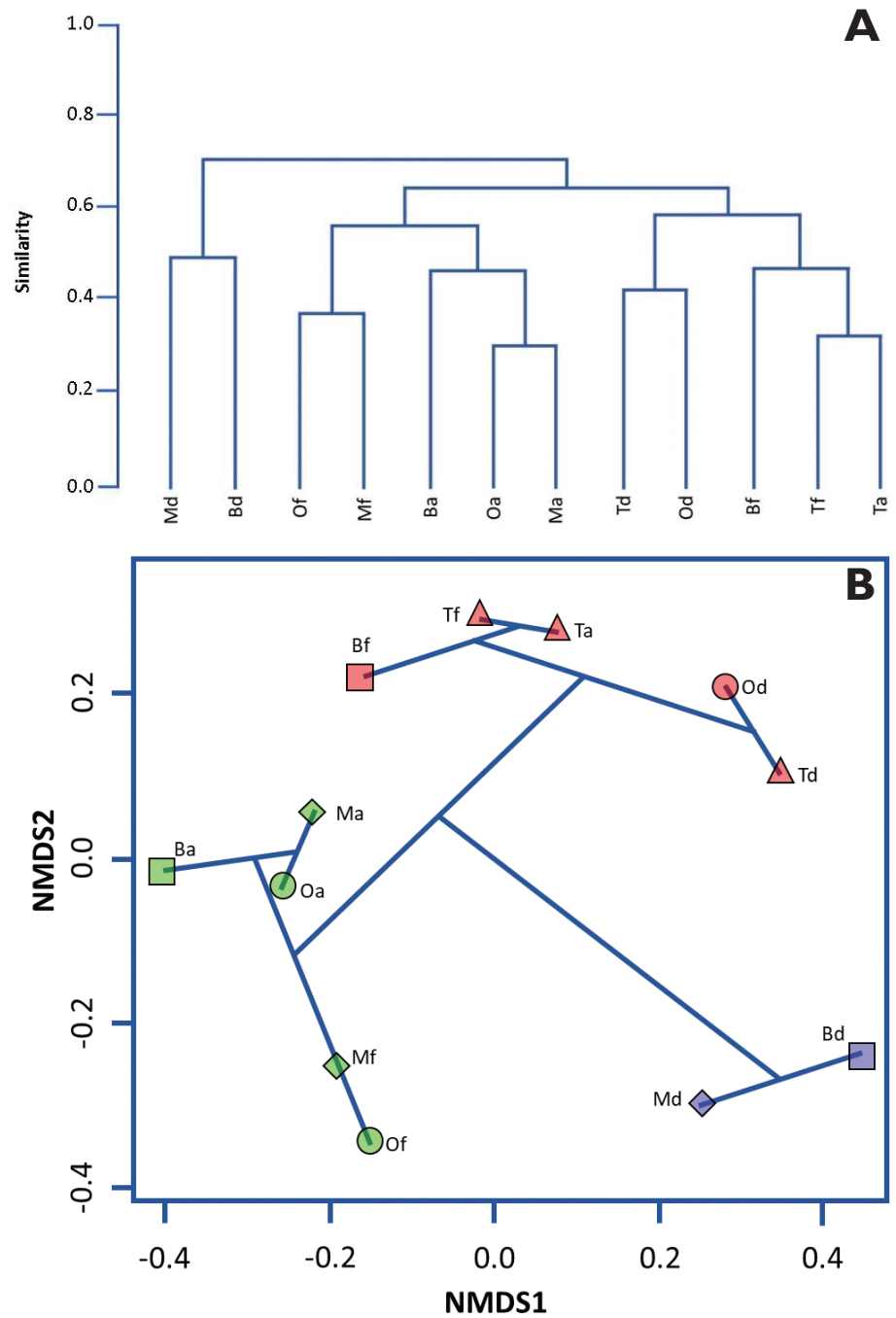

Figure 4. A Dendrogram and B non-metrical multidimensional scaling (nMDS) ordination plot, both resulting from the similarity matrix based on Jaccard's similarity index. 
was similar to Bang, but significantly different from Tábano and Muknal (Hutcheson T-test, Fig. 2C). Out of the 15 species recorded, the only one restricted to the salt water layer was the remipede Xibalbanus tulumensis, always found below the halocline in the three internal cenotes (Fig. 3). The remaining 14 species occurred mainly in the freshwater/brackish layer, however, five of them had occasional occurrences below the halocline (Fig. 3). None of the environmental variables used in the multivariate analysis of variance showed a significant effect on species abundance per site; $\mathrm{pH}$,which was the most relevant variable, explained only $15 \%$ of the total variance (Table 3 ).

The analysis of similarity shows three groups in which all four cenotes and the three surveys are mixed (Fig. 4A, B). One group is formed by the samples of Muknal and Bang in December, while the other two groups cannot be defined clearly. The obtained pattern may indicate that there is no marked zonation within the cave in terms of species composition.

\section{Discussion}

The obtained results on the distribution and abundance of anchialine fauna along a 10.2 $\mathrm{km}$ transect in the $\mathrm{OBH}$ cave, suggest the existence of a high connectivity throughout the conduits that prevent a horizontal zonation. The hydrology of this area along the Caribbean coast of the YP has been studied showing the presence of a dynamic "subterranean estuary" where saline water penetrates inland below a freshwater lens and where groundwater discharge can be considerably high (Beddows 2004). Our temperature and salinity measurements along the transect are consistent with what would be expected according to the ground water circulation model of Beddows et al. (2007), in which near the coast salinity above the halocline is higher and the temperature difference between water layers is larger, and where with increasing distance from the coast salinity decreases above the halocline and the temperature of the two water masses tends to be the same (Table 1). These data evidence a hydrological continuum that is preserved by the circulation occurring through the large underground conduits (cave passageways) in the area.

The hydrological connectivity amongst caves within the anchialine system in this area of the YP allows species to distribute throughout the conduits without a defined pattern. Our results show that most of the recorded species can occur in any section of the studied cave system. The limitation for the species that are restricted to the high salinity water mass, such as the remipede $X$. tulumensis, in this particular branch of the $\mathrm{OBH}$ would be the absence of a marine layer due to the shallow conduits. The conduits develop at a depth of 12 to $14 \mathrm{~m}$, but with an irregular bathymetry large sections of cave could be above the level of the halocline. In contrast, the freshwater species can exlpoit a much larger area.

The number of anchialine species recorded in this study (15) represents about $27 \%$ of the known diversity for the anchialine caves of the YP (Alvarez and Iliffe 2008, Alvarez et al. 2015, Olesen et al. 2017). The assemblage of species found in the $\mathrm{OBH}$ system includes both, common and widely distributed throughout the YP (e.g., 
Creaseriella anops, Creaseria morleyi, Typhlatya mitchelli) and some rare ones which are present in this area only (e.g., Xibalbanus tulumensis, Calliasmata nohochi).

While species composition along the transect did not show any defined pattern, abundance of organisms shows a slight, not significant, trend to decrease with increasing distance from the coast. The amount of nutrients could be increasing towards the coast where organic matter that enters via cenotes or percolation from the rainforest floor accumulates due to the circulation of freshwater (Beddows et al. 2007); however, near the coast is also where human impact is occurring more intensely (HernándezTerrones et al. 2011). Alternatively, natural cycling of carbon and nutrients takes place in conserved areas where decomposition on the rainforest floor is connected to the water mass contained in the caves (Brankovits et al. 2017). In any case, precise data on the amount of available nutrients throughout a transect as the one studied here are lacking.

The obtained results suggest that isolation within a cave along the Caribbean coast of the YP would not be significant to allow for population differentiation. The high degree of connectivity represents a continuum, at least in the freshwater/brackish water layer above the halocline, allowing for free movement of organisms. Thus, the scale of variation among populations that would be expected would correspond to a regional scale throughout the YP. In fact, several species endemic to this part of the YP (such as the remipede Xibalbanus tulumensis, and the amphipod Tuluweckelia cernua) are common in the whole Caribbean cave area that runs from Puerto Morelos to Tulum, in the state Quintana Roo.

\section{Conclusion}

The sampling along the transect in the $\mathrm{OBH}$ cave shows that the anchialine fauna is distributed throughout the flooded cave without a defined pattern. The hydrological data obtained is consistent with a high connectivity system typical of the cavernous area in this part of the Caribbean coast of Mexico. As expected most of the anchialine fauna found are freshwater species, with only a few restricted to the high salinity water mass.

\section{Acknowledgements}

The first author gratefully acknowledges the Posgrado en Ciencias del Mar y Limnología, UNAM, for providing the means to conduct this study and the financial support through aCONACYT scholarship. We are indebted to José Luis Villalobos, Olinka Cortés, Brenda Durán, Arturo Mora, Bil Phillips, David Brankovits, Tyler Winkler and Brett Gonzalez for their help in the field, diving and processing samples and data. Field work was conducted with funding from two $(2014,2018)$ Texas A\&M - CONACYT Collaborative Research Grants awarded to T.M. Iliffe and F. Alvarez. Funding from DGAPA-PAPIIT-UNAM grant IN208519 and CONACYT grant 155644 awarded to F. Alvarez are also acknowledged. 


\section{References}

Alvarez F, Iliffe TM (2008) Fauna anquihalina de Yucatán. In: Alvarez F, Rodríguez-Almaraz (Eds) Crustáceos de México: Estado actual de su conocimiento. Universidad Autónoma de Nuevo León, Monterrey, Nuevo León, México, 379-418.

Alvarez F, Ojeda M (2018) First record of a sea spider (Pycnogonida) from an anchialine habitat. Latin American Journal of Aquatic Research 46: 219-224. https://doi.org/10.3856/ vol46-issue1-fulltext-21

Alvarez F, Iliffe TM, Villalobos JL (2005) New species of the genus Typhlatya Creaser, 1936 (Decapoda: Atyidae) from anchialine caves in Mexico, the Bahamas and Honduras. Journal of Crustacean Biology 25: 81-94. https://doi.org/10.1651/C-2516

Alvarez F, Iliffe TM, Villalobos JL (2017) A new anchialine species of Naushonia (Decapoda: Gebiidea: Laomediidae) from the Bahamas. Zootaxa 4258: 187-194. https://doi. org/10.11646/zootaxa.4258.2.8

Alvarez F, Iliffe TM, Benítez S, Brankovits D, Villalobos JL (2015) New records of anchialine fauna from the Yucatan Peninsula, Mexico. CheckList 11: 1505. https://doi. org/10.15560/11.1.1505

Alvarez F, Benítez S, Iliffe TM, Villalobos JL (2019) A new species of isopod of the genus Curassanthura (Cymothoida, Anthuroidea, Leptanthuridae) from anchialine caves of the Yucatan Peninsula, Mexico. Crustaceana 92: 545-553. https://doi.org/10.1163/1568540300003892

Beddows PA (2004) Groundwater hydrology of a coastal conduit carbonate aquifer: Caribbean coast of the Yucatan Peninsula, Mexico. PhD Thesis, University of Bristol, UK, 303 pp.

Beddows PA, Smart PL, Whitaker FF, Smith SL (2007) Decoupled fresh-saline groundwater circulation of a coastal carbonate aquifer: spatial patterns of temperature and specific electrical conductivity. Journal of Hydrology 346 (1): 18-32. https://doi.org/10.1016/j. jhydrol.2007.08.013

Botello A, Alvarez F (2006) Allometric growth in Creaseria morleyi (Creaser, 1936) (Decapoda: Palaemonidae), from the Yucatan Peninsula, Mexico. Caribbean Journal of Science 42(2): 171-179.

Botello A, Alvarez F (2010) Genetic variation in the stygobitic shrimp Creaseria morleyi (Decapoda: Palaemonidae): evidence of bottlenecks and re-invasions in the Yucatan Peninsula. Biological Journal of the Linnean Society 99: 315-325. https://doi.org/10.1111/j.10958312.2009.01355.x

Botello A, Iliffe TM, Alvarez F, Juan C, Pons J, Jaume D (2013) Historical biogeography and phylogeny of Typhlatya cave shrimps (Decapoda: Atyidae) based on mitochondrial and nuclear data. Journal of Biogeography 40: 594-607. https://doi.org/10.1111/jbi.12020

Botosaneanu L, Iliffe TM (1997) Four new stygobitic cirolanids (Crustacea: Isopoda) from the Caribbean - with remarks on intergeneric limits in some cirolanids. Bulletin de l'Institut Royal des Sciences Naturelles de Belgique, Biologie 67: 77-94.

Bowman TE (1977) A review of the genus Antromysis (Crustacea: Mysidacea), including new species from Jamaica and Oaxaca, Mexico, and a redescription for A. cenotensis. Association for Mexican Cave Studies, Bulletin 6: 27-38. 
Bowman TE (1987) Bahalana mayana, a new troglobitic cirolanid isopod from Cozumel Island and the Yucatan Peninsula, Mexico. Proceedings of the Biological Society of Washington 100: 659-663.

Bowman TE, Iliffe TM (1988) Tulumella unidens, a new genus and species of thermosbaenacean crustacean from the Yucatan Peninsula, México. Proceedings of the Biological Society of Washington 101: 221-226.

Bowman TE, Iliffe TM, Yager J (1984) New records of the troglobitic mysid genus Stygiomysis: S. clarkei, new species, from the Caicos Islands, and S. holthuisi (Gordon) from Grand Bahama Island (Crustacea: Mysidacea). Proceedings of the Biological Society of Washington 97: 637-644.

Brankovits D, Pohlman J, Niemann H, Leigh M, Leewis MC, Becker K, Iliffe TM, Alvarez F, Lehmann M, Phillips B (2017) Methane- and dissolved organic carbon- fueled microbial loop supports a tropical subterranean estuary ecosystem. Nature Communications 8: 1835. https://doi.org/10.1038/s41467-017-01776-x

Calderón-Gutiérrez F, Sánchez-Ortiz C, Huato-Soberanis L (2018) Ecological patterns in anchialine caves. PloS One 13: e0202909. https://doi.org/10.1371/journal.pone.0202909

Clarke KR, Warwick RM (2001) Change in marine communities: an approach to statistical analysis and interpretation. PRIMER-E, Plymouth.

Escobar-Briones E, Camacho ME, Alcocer J (1997) Calliasmata nohochi, new species (Decapoda: Caridea: Hippolytidae), from anchialine cave systems in continental Quintana Roo, Mexico. Journal of Crustacean Biology 17: 733-744. https://doi.org/10.2307/1549376

Field JG, Clarke KR, Warwick RM (1982) A practical strategy for analyzing multispecies distribution patterns. Marine Ecology Progress Series 8: 37-52. https://doi.org/10.3354/ meps008037

Gonzalez BC, Iliffe TM, Macalady JL, Schaperdoth I, Kakuk B (2011) Microbial hotspots in anchialine blueholes: initial discoveries from the Bahamas. Hydrobiologia 677: 149-156. https://doi.org/10.1007/s10750-011-0932-9

Havird JC, Vaught RC, Weese DA, Santos SR (2015) Reproduction and development in Halocaridina rubra Holthuis, 1963 (Crustacea: Atyidae) clarifies larval ecology in Hawaiian anchialine ecosystem. Biological Bulletin 229: 134-142. https://doi.org/10.1086/ BBLv229n2p134

Hernández-Terrones L, Rebolledo-Vieyra M, Merino-Ibarra M, Soto M, Le-Cossec A, Monroy-Ríos E (2011) Groundwwater pollution in a karstic region (NE Yucatan): baseline nutrient content and flux to coastal ecosystems. Water, Air \& Soil Pollution 218: 517-528. https://doi.org/10.1007/s11270-010-0664-x

Holsinger JR (1990) Tuluweckelia cernua, a new genus and species of stygobiont amphipod crustacean (Hadziidae) from anchialine caves on the Yucatan Peninsula of Mexico. Beaufortia 41: 97-107.

Humphreys WF (1999) Physico-chemical profile and energy fixation in Bundera Sinkhole, an anchialine remipede habitat in north-western Australia. Journal of the Royal Society of Western Australia 82: 89-98.

Iliffe TM (2018) Collecting and processing crustaceans from anchialine and marine caves. Journal of Crustacean Biology 38: 374-379. https://doi.org/10.1093/jcbiol/ruy011 
Iliffe TM, Alvarez F (2018) Chapter 18. Research in anchialine caves. In: Moldovan OT, Kováč L, Halse S (Eds) Cave Ecology, Ecological Studies 235. Springer Nature Switzerland AG. https://doi.org/10.1007/978-3-319-98852-8_18

Kallmeyer DE, Carpenter J (1996) Stygiomysis cokei, new species, a troglobitic mysid from Quintana Roo, Mexico (Mysidacea: Stygiomysidae). Journal of Crustacean Biology 16: 418-427. https://doi.org/10.2307/1548897

Kornicker LS, Iliffe TM (1998) Mydocopid Ostracoda (Halocypridina, Cladocopina) from anchialine caves in the Bahamas, Canary Islands, and Mexico. Smithsonian Contributions to Zoology 599: 1-93. https://doi.org/10.5479/si.00810282.599

Legendre P, Legendre L (2012) Numerical ecology ( $3^{\text {rd }}$ edn). Elsevier Science, Amsterdam.

Magurran AE (1988) Ecological diversity and its measurement. New Jersey, Princeton University. https://doi.org/10.1007/978-94-015-7358-0

Martínez-García A, Palmero AM, Brito MC, Nuñez J, Worsaae K (2009) Anchialine fauna of the Corona lava tube (Lanzarote, Canary Islands): diversity, endemism and distribution. Marine Biodiversity 39: 169-182. https://doi.org/10.1007/s12526-009-0023-6

Olesen J, Meland K, Glenner H, Van Hengstum PJ, Iliffe TM (2017) Xibalbanus cozumelensis, a new species of Remipedia (Crustacea) from Cozumel, Mexico, and a molecular phylogeny of Xibalbanus on the Yucatán Peninsula. European Journal of Taxonomy 316: 1-27. https://doi.org/10.5852/ejt.2017.316

Pohlman JW, Iliffe TM, Cifuentes LA (1997) A stable isotope study of organic cycling and the ecology of an anchialine cave ecosystem. Marine Ecology Progress Series 155: 17-27. https://doi.org/10.3354/meps 155017

QRSS (2018) Quintana Roo Speleological Survey. http://caves.org/project/qrss/qrss.htm

R Development Core Team (2018) R: A language and environment for statistical computing. R Foundation for Statistical Computing, Vienna. https:/www.R-project.org

Shannon CE, Weaver W (1949) The Mathematical Theory of Communication. University Illinois Press, Urbana, IL.

Smart PL, Beddows PA, Coke J, Doerr S, Smith S, Whitaker FF (2006) Cave development on the Caribbean coast of the Yucatan Peninsula, Quintana Roo, Mexico. In: Harmon RS, Wicks C (Eds) Perspectives on karst geomorphology, hydrology, and geochemistry - A tribute volume to Derek C. Ford and William B. White. Geological Society of America Special Paper 404: 105-128. https://doi.org/10.1130/2006.2404(10)

Suárez-Morales E, Gutiérrez-Aguirre MA, Cervantes-Martínez A, Iliffe TM (2017) A new anchialine Stephos Scott fromYucatan Peninsula with notes on the biogeography and diversity of the genus (Copepoda, Calanoida, Stephidae). Zookeys 671: 1-17. https://doi. org/10.3897/zookeys.671.12052

Yager J (1987) Speleonectes tulumensis n sp. (Crustacea, Remipedia) from two anchialine cenotes of the Yucatan Peninsula. Stygologia 3: 160-166. 